\title{
TRAVEL VACCINE
}

\author{
Lia Dwi Lestari ${ }^{1)}$, Raveinal ${ }^{2}$ \\ ${ }^{1}$ PPDS Ilmu Penyakit Dalam Fakultas Kedokteran Universitas Andalas/RSUP M. Djamil Padang \\ email: yute_kla@yahoo.com \\ ${ }^{2}$ Subbagian Alergi Imunologi Ilmu Penyakit Dalam Fakultas Kedokteran Universitas Andalas/RSUP M. Djamil \\ Padang
}

Submitted : 31-05-2020, Reviewer:04-06-2020, Accepted: 04-06-2020

\begin{abstract}
Abstrak
Perjalanan wisata sangat bisa berpotensi dalam penularan suatu penyakit, terutama penyakit-penyakit yang ditularkan melalui batuk atau bersin. Penularan ini dapat terjadi dengan sangat cepat, bahkan dapat menyebar sampai ke seluruh dunia, dapat pula berakibat fatal bahkan menimbulkan kematian. Beberapa contoh penyakit menular yang bisa didapat oleh para traveller misalnya : Hepatitis A, Influenza, Yellow Fever, Japanese Encephalitis, Meningitis, yang sebenarnya kesemua penyakit tersebut dapat dicegah dengan vaksin, namun para penggemar travel umumnya masih banyak yang belum mengetahui akan pentingnya vaksinasi sebagai salah satu cara penting melindungi kesehatan tubuh. Vaksinasi diartikan sebagai tindakan pemberian suatu vaksin sedangkan imunisasi didefinisikan suatu induksi agar terjadi pembentukan imunitas tubuh. Sampai saat ini imunisasi dianggap salah satu bentuk intervensi yang paling cost- effective untuk mencegah penularan penyakit infeksi selama perjalanan, dikarenakan respon imun dalam pemberian vaksinasi yakni : sel limfosit (limfosit B dan T) dan APC (Antigen Precenting Cell) misalnya sel dendritik dan makrofag, merupakan respon tubuh utama dalam upaya eliminasi berbagai antigen.
\end{abstract}

Kata Kunci: Travel Vaccine, vaksinasi, imunisasi, respon imun

\begin{abstract}
Tourism can be very potential in transmitting a disease, especially diseases transmitted through coughing or sneezing. This transmission can occur very quickly, even spread throughout the world, can also be fatal and even cause death. Some examples of infectious diseases that can be obtained by travelers such as: Hepatitis A, Influenza, Yellow Fever, Japanese Encephalitis, Meningitis, which actually all of these diseases can be prevented by vaccines, but there are still many travel enthusiasts who do not yet know the importance of vaccination as a wrong one important way to protect body health. Vaccination is defined as the act of giving a vaccine while immunization is defined as an induction so that the formation of the body's immunity occurs. Until now, immunization is considered one of the most cost-effective forms of intervention to prevent transmission of infectious diseases during travel, due to the immune response in vaccination namely: lymphocyte cells (B and T lymphocytes) and APC (Antigen Precenting Cell) such as dendritic cells and macrophages, is the body's main response in the effort to eliminate various antigens.
\end{abstract}

Keywords: Travel Vaccine, vaccination, immunization, immune response

\section{PENDAHULUAN}

Vaksin merupakan sediaan biologis yang menimbulkan suatu kekebalan terhadap penyakit, didalamnya terkandung sejumlah kecil bahan yang menyerupai organisme patogen yang mampu menginduksi sistem imun.Vaksinasi merupakan tindakan pemberian suatu vaksin. ${ }^{1}$ Di dalam Peraturan Menteri Kesehatan Republik Indonesia Nomor 42 tahun 2013 tentang penyelenggaran imunisasi, imunisasi didefinisikan sebagai suatu upaya, untuk menimbulkan atau meningkatkan kekebalan seseorang secara aktif terhadap suatu penyakit, sehingga bila suatu saat terpajan 
dengan penyakit tersebut tidak akan sakit atau mengalami sakit ringan. ${ }^{2}$

Dalam buku International Travel and Health" 2007 dari World Health Organization, dikatakan bahwa statistik tahun 2005 dari The World Tourism Organization, kunjungan turis seluruh dunia telah melebihi 800 juta orang, mayoritas sebanyak 50\% atau sekitar 402 juta adalah turis internasional dengan tujuan kunjungan berlibur, rekreasi dan bersenang-senang, lalu sebanyak $42 \%$ atau sekitar 337 juta adalah turis untuk kunjungan teman dan keluarga, wisata agama seperti ibadah Haji dan untuk mencari pengobatan, sisanya sekitar 8\% adalah turis yang tidak jelas tujuan kunjungannya. ${ }^{3}$

Travel Vaccine atau vaksin wisatawan merupakan imunisasi khusus yang diberikan kepada para wisatawan sebelum mereka pergi ke daerah yang mereka inginkan. Namun penggunaan vaksin di kalangan traveler belum popular dan umumnya masih banyak penggemar travel yang belum mengetahui akan pentingnya vaksinasi sebagai salah satu cara penting melindungi kesehatan tubuh. $^{3}$

\section{RESPON IMUN PADA VAKSINASI}

Imunitas manusia terdiri dari 2 tipe yaitu:

1. Imunitas pasif

Terbentuk melalui pemberian antibodi dalam bentuk imunoglobulin, baik spesifik maupun non spesifik

2. Imunitas aktif

Terbentuk melalui pemaparan antigen dari suatu patogen terhadap sistem imunitas penjamu, sehingga terbentuk suatu antibody

Respons imun merupakan respon tubuh yang berupaya mengeliminasi antigen. Komponen penting dalam menimbulkan respon imun dalam pemberian vaksinasi adalah sel limfosit (limfosit B dan $\mathrm{T}$ ) dan APC (Antigen Precenting Cell) misalnya sel dendritik dan makrofag. ${ }^{1,3}$
Terdapat dua kelompok besar respons imun.

a. Respons imun non spesifik (non adaptive, innate) yang ditujukan tidak hanya pada 1 antigen, berupa komponen seluler (makrofag, neutrofil, sel natural killer (NK) dan komponen humoral (sitokin, interferon) b. Respon imun spesifik (adaptive, acquired) yang ditujukan spesifik hanya pada 1 antigen. Pada respon imun spesifik ini terdapat dua komponen seluler (limfosit $\mathrm{T}$ ) dan komponen humoral (limfosit B yang memproduksi antibodi). ${ }^{4}$

Respon sel $\mathrm{T}$ terhadap invasi antigen (termasuk antigen vaksin) hanya dapat dimulai bila antigen sudah diproses dan dipresentasikan oleh Antigen Presenting Cell (APC). Hal ini timbul karena sel $\mathrm{T}$ hanya dapat mengenali antigen yang terikat pada protein Major histocompability Complex (MHC). Terdapat 2 kelas MHC, yang masing-masing dapat dikenali oleh 1 dari 2 subtipe sel T. MHC kelas 1 diekspresikan oleh seluruh sel somatik, untuk mempresentasikan antigen pada sel $\mathrm{T}$ sitotoksik (Cytotoxic T Lymphocytes, CTL) dengan petanda permukaan CD8 yang dapat menyebabkan kematian sel terinfeksi atau patogen. Sedangkan, MHC kelas II diekspresikan oleh makrofag dan beberapa sel lain untuk mempresentasikan antigen pada sel $\mathrm{T}$ helper (Th) dengan petanda permukaan CD4. ${ }^{5}$ 


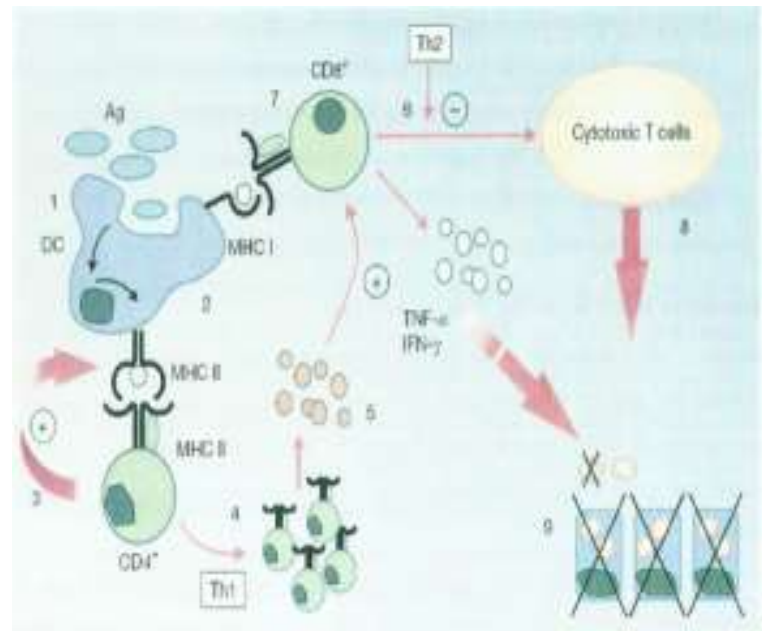

Gambar 1. Respon Imun Spesifik Primer Seluler Pasca Paparan Antigen Vaksin ${ }^{5}$

Bersama dengan sinyal kostimulator, antigen yang telah terikat pada MHC kelas 2 akan menghasilkan sel Th. Kemudian sel Th akan berdiferensiasi menjadi sel Th1 dan Th2. Aktivasi sel Th juga menyebabkan sel sekresi interleukin-2 (IL-2) dan ekspresi reseptor spesifik IL-2 pada permukaan sel Th. IL-2 bekerja autokrin dengan memicu sel $\mathrm{T}$ agar lebih aktif melakukan proliferasi dan memproduksi berbagai sitokin yang memicu pertumbuhan, perkembangan sel B, makrofag dan sel lainnya.

Kontak antigen dan Th juga menstimulasi pengeluaran IL-1 oleh APC dan Th. Kerja IL-1 sebagai autokrin ini meingkatkan ekspresi MHC kelas II pada APC yang akan memperkuat ikatan APC dan Th. Dua sitokin lain yang juga dihasilkan makrofag, yaitu Tumor Necrosis Factor (TNF) dan IL-6, bekerja sebagai sinergis dengan IL-1. Sel Th yang teraktivasi juga menyebabkan diferensiasi sel $\mathrm{T}$ menjadi sel $\mathrm{T}$ memori yang berperan pada respons imun spesifik sekunder. ${ }^{4}$

Pada respon imun spesifik primer humoral, reseptor Ig pada permukaan sel B saat dirangsang oleh antigen protein, akan mengenali dan berinteraksi dengan epitop dan antigen, baik secara langsung atau pun dengan bantuan sitokin (IL-2, IL-4, dan IL_6) yang dihasilkan sel Th. Sel B yang telah teraktivasi akan berdiferensiasi menjadi sel plasma dan sel B memori yang berperan pada respon imun spesifik sekunder. Sel plasma inilah yang menghasilkan antibodi spesifik. Perangsangan oleh antigen polisakarida turut mencetuskan reaksi serupa. Akan tetapi, tidak terjadi reaksi imunitas humoral yang dibantu oleh sel $\mathrm{T}$ pada pusat germinal. Perbedaan lainnya adalah sel plasma yang timbul akibat perangsangan oleh antigen protein akan berimigrasi dan tersimpan pada sumsum tulang, sedangkan sel plasma yang timbul akibat perangsangan oleh antigen polisakarida akan tersimpan pada limpa. ${ }^{4}$

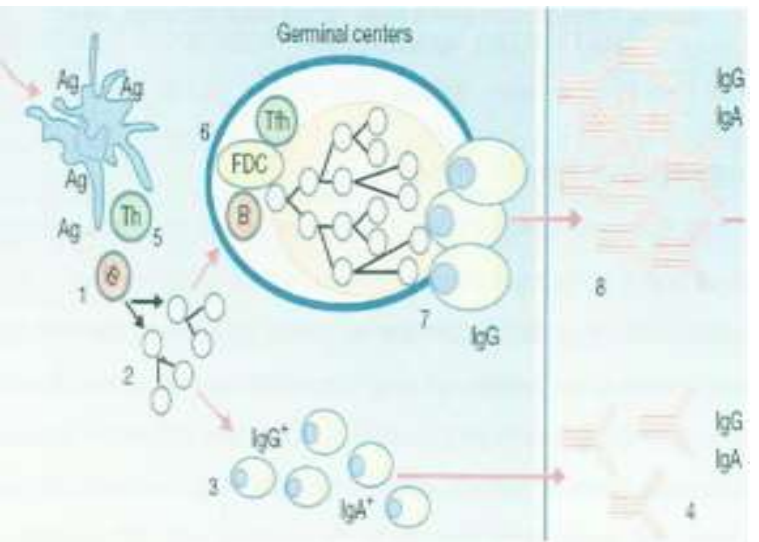

Gambar 2. Respons Imun Spesifik Primer Humoral Akibat Rangsangan Antigen protein ${ }^{4}$

Pada respon imun spesifik sekunder humoral, sebagai respon terhadap adanya infeksi primer, terjadi diferensiasi sel B menjadi sel plasma dan sel memori pada germinal center jaringan limfoid. Kemudian sel plasma bermigrasi ke sumsum tulang dan sel memori bersirkulasi ke seluruh tubuh. Ketika sel memori beredar kembali ke jaringan limfoid yang mengandung antigen serupa, siklus diferensiasi menjadi berlangsung lebih cepat, sehingga diproduksi antibodi dengan afinitas dan jumlah yang lebih tinggi. Berbeda dengan respon imun humoral primer yang awalnya menghasilkan IgM dilanjutkan dengan IgG dalam kadar lebih tinggi. 


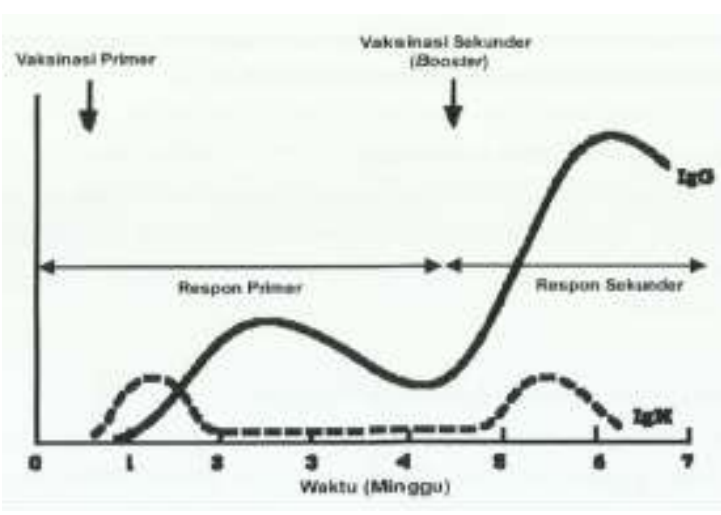

Gambar 3. Kadar Antibodi Pada Respons Imun Humoral Primer dan Sekunder ${ }^{4}$

\section{JENIS DAN PEMBUATAN VAKSIN}

Jenis vaksin yang digunakan untuk imunisasi terdiri dari berbagai bentuk, yaitu:

1. Vaksin yang dilemahkan (attenuated live vaccine)

Viabilitas dan daya infeksi kuman atau virus dilemahkan namun masih mampu menumbuhkan respon imun. Vaksin ini berasal dari keseluruhan organisme atau bagian dari organisme atau bagian dari organisme

2. Vaksin yang telah dimatikan (killed vaccine, inactivated vaccine)

Berasal dari mikroorganisme yang telah dimatikan. Respon imun yang timbul lebih lemah daripada vaksin hidup sehingga biasanya memerlukan imunisasi ulang. Contoh vaksin ini adalah kolera dan pertusis.

Jenis vaksin ini dapat juga dibagi menjadi:

a. Vaksin subunit

Vaksin berasal dari bagian organisme.

Misalnya komponen kapsul bakteri (Streptococcus pneumonia).

Keuntungan vaksin ini telah aman diberikan pada anak serta terhindar dari vaksin yang purulen.

b. Vaksin toksoid
Vaksin ini dibuat dari bahan toksin bakteri tidak toksik namun dapat merangsang pembuatan antibodi. Contohnya: tetanus dan difteri

c. Vaksin konjugat

Vaksin ini merupakan polisakarida murni yang kurang imunogenik untuk anak di bawah usia dua tahun. Untuk meningkatkan imunogenisitas, polisakarida dikonjugasikan dengan protein karier sehingga dapat meningkatkan respon imun

3. Vaksin Rekombinan

Susunan vaksin ini memerlukan epitop organisme yang patogen. Sintesis dari antigen vaksin tersebut melalui isolasi dan penentuan gen epitop bagi sel penerima vaksin. Prinsip vaksin ini adalah dengan menyisipkan satu atau lebih gen yang mengkode determinan imunitas yang penting pada mikroorganisme. Vektor yang biasa digunakan adalah virus (poxvirus vaccinia, canarypox, adenovirus) dan bakteri (salmonella). Contoh vaksin ini adalah vaksin hepatitis B

4 Vaksin Plasma DNA (Plasmid DNA Vaccines)

Vaksin dibuat berdasarkan isolasi DNA mikroba yang mengandung kode antigen yang patogen dan masih dalam perkembangan penelitian. Hasil akhir pada binatang percobaan menunjukkan bahwa vaksin DNA (virus dan bakteri) merangsang respon humoral dan selular yang cukup kuat sedangkan penelitian klinis pada manusia saat ini sedang dilakukan. ${ }^{1,6}$

\section{KATEGORI TRAVEL VACCINE}

1 Vaksin Rutin

Jika terdapat riwayat imunisasi yang tidak lengkap, calon wisatawan dianjurkan untuk mendapat imunisasi dasar terlebih dahulu agar status imunisasinya menjadi lengkap. 
Vaksin rutin merupakan imunisasi dasar yang termasuk ke dalam kebanyakan program kesehatan nasional. Vaksin-vaksin ini biasanya diberikan kepada anak-anak dan umumnya diberikan suntikan booster (pendorong) agar kekebalan yang dihasilkan dapat lebih efektif. Ada berbagai macam vaksin rutin mulai dari campak, campak Jerman, difteri, pertusis, tetanus, polio, hepatitis B, sampai influenza B. Pada beberapa negara, vaksin untuk cacar, rotavirus, HPV, BCG dan tuberkulosis juga dimasukkan ke dalam program imunisasi rutin. Bagi beberapa golongan dengan usia tertentu vaksin influenza juga menjadi salah satu vaksin rutin.

2 Vaksin Rekomendasi

Vaksin rekomendasi merupakan imunisasi yang diberikan kepada mereka yang akan berpergian ke daerah dengan tingkat paparan penyakit tertentu yang tinggi. Vaksin yang termasuk ke dalam jenis ini adalah vaksin kolera, hepatitis A, rabies dan demam tifoid, dan diberikan terutama bagi mereka yang akan berpergian ke Asia dan Amerika Selatan. Penambahan vaksin Japanese Ensefalitis diberikan bagi mereka yang berpergian ke negara Asia tertentu dan vaksin Ensefalitis tick-borne kepada yang berpergian ke Rusia dan negara Baltik.

3 Vaksin Wajib

Hanya 3 macam vaksin yang merupakan vaksin wajib yaitu vaksin demam kuning, meningokokal dan polio. Dari ketiga vaksin tersebut, Peraturan Kesehatan Internasonal mewajibkan vaksin demam kuning sebagai vaksin yang wajib diberikan. Para wisatawan yang berpergian ke benua Afrika dan hampir semua negara di Amerika Tengah dan Selatan diwajibkan untuk mendapat imunisasi demam kuning. Beberapa negara bahkan mewajibkan ini kepada wisatawan yang mengunjungi negara wabah demam kuning hanya untuk transit. Mereka yang sudah mendapat imunisasi demam kuning akan diberi sertifikat internasional sebagai bukti nyata. Negara Saudi Arabia mewajibkan vaksinasi meningokokal kepada mereka yang pergi ke Mekah untuk naik haji. Beberapa negara juga mewajibkan vaksin polio bagi wisatawan yang kembali dari negara yang memiliki laporan adanya poliomielitis tipe liar. ${ }^{2,6,7}$

\section{WAKTU PEMBERIAN VACCINE}

Vaksin akan bekerja dua minggu setelah disuntik. Jadi, waktu yang paling aman untuk melakukan suntik vaksin adalah satu bulan sebelum melakukan travel. Hal tersebut dikarenakan, antibodi baru akan terbentuk selama dua minggu setelah dimasukkan vaksin. Vaksin tersebut kemudian akan aktif selama tiga tahun.

Secara umum, vaksin yang tidak aktif dapat diberikan pada waktu yang sama. Vaksin hidup dapat diberikan bersamaan namun harus diberikan melalui jalur masuk yang berbeda. Bila ini tidak dapat dilakukan maka vaksin tersebut perlu diberikan 1 bulan setelahnya. Vaksin kombinasi dapat memberikan kenyamanan bagi wisatawan karena mereka mendapatkan imunisasi yang berbeda dalam 1 suntikan. ${ }^{3,6}$

\section{JENIS TRAVEL VACCINE}

\section{Vaksin Influenza}

Vaksin diberikan setiap tahun bagi orang dewasa dengan usia $\geq 50$ tahun, penghuni rumah jompo dan fasilitas-fasilitas lain dalam waktu lama, orang muda dengan penyakit jantung, paru kronis, penyakit metabolisme, disfungsi ginjal, hemoglobinopati atau imunosupresi, HIV, perawat dan petugas-petugas kesehatan diatas. $^{3,6}$

Macam : vaksin split atau subunit

Efektivitas : $88-89 \%$ 
Rute : suntikan intramuskular

Catatan : vaksin ini dianjurkan untuk usia $\geq 50$ tahun untuk individual sedangkan untuk program usia $\geq 65$ tahun

Terdapat 2 jenis vaksin influenza ${ }^{8}$

a. Vaksin inaktif

Virus yang divaksinasikan berkembang biak dan merangsang pembentukan antibodi seperti pada reaksi cell-mediated immunity.

- whole virion vaccine

Menggunakan seluruh partikel virus, mempunyai imunogenisitas yang baik, tetapi konsekuensi efek samping lebih besar.

- split particle vaccin

Menggunakan fragmen partikel virus (mengandung RNA dan protein $\mathrm{M}$ ), antigen permukaan dan struktur protein dan antigen pelarut seluruhnya diikutsertakan. Mempunyai imunogenisitas cukup baik dan efek samping yang lebih sedikit

- subunit vaccine

Hanya mengandung HA dan NA. Bentuknya mirip dengan split particle vaccine, tetapi proses pemurniannya berbeda. Mempunyai imunogenisitas yang kurang efek samping sedikit

Vaksin ini diberikan intramuskular dan berisi tiga visus inaktif: tipe A (H1N1), tipe $\mathrm{A}(\mathrm{H} 3 \mathrm{~N} 2)$ dan tipe B. Untuk dosis dewasa diberikan $0,5 \mathrm{ml}$

b. Vaksin hidup

Vaksin ini berisi sama dengan vaksin inaktif, diberikan secara rute infeksi natural secara intranasal. Vaksin ini hanya boleh diberikan pada individu sehat dan tidak hamil, berusia 2-49 tahun. Di Amerika Serikat vaksinasi influenza sangat dianjurkan. Center for Disease Control and Prevention (CDC) dan Advisory Committee on Immunization Practices (ACIP) menetapkan kelompok masyarakat yang harus mendapat prioritas vaksinasi influenza pada tahun 2005-2006, yaitu: ${ }^{9,10}$

a. kelompok usia $\geq 65$ tahun dengan atau tanpa penyakit komorbid

b. penghuni tempat rawatan kesehatan

c. kelompok usia 2-64 tahun dengan penyakit komorbid

d. anak usia6-23 bulan

e. wanita hamil

f. petugas kesehatan yang melayani langsung penderita

g. keluarga yang serumah dengan penderita dan pengasuh anak usia < 6 bulan

2. Vaksin Hepatitis A

Pencegahan infeksi virus hepatitis A melalui imunisasi dapat diberikan dalam dua bentuk: $:^{1,6,11}$

a. Imunisasi pasif

Diberikan pada individu yang rentan pada paparan melalui pemberian imunoglobulin . Direkomendasikan pada individu pasca paparan virus dan yang belum divaksin hepatitis $\mathrm{A}$ dan beresiko terpapar dalam waktu kurang dari 2 minggu. Hasil dari pemberian imunoglobulin ini adalah serokonversi, yaitu terbentuknya antibodi yang bersifat protektif setelah pemberian imunoglobulin

b. Imunisasi aktif

Vaksin yang diberikan berupa virus yang dilemahkan. Virus ini dinaktivasi oleh formalin dan merupakan whole vaccine yang diproduksi dari kultur sel.

Vaksin Hepatitis A diberikan dua dosis dengan jarak 6 hingga 12 bulan pada individu beresiko terjadinya infeksi virus Hepatitis A dan mereka yang menginginkan imunitas. Populasi yang beresiko tinggi tersebut adalah:

a. Individu yang sering melakukan perjalanan atau bekerja di suatu negara yang mempunyai prevalensi tinggi hepatitis A 
b. Homoseksual

c. Pengguna narkoba

d. Penderita penyakit hati

e. Individu yang bekerja dengan hewan primata terinfeksi hepatitis A

f. Peneliti virus hepatitis A

Macam vaksin : antigen virus inaktif

Efektivitas : :94-100\%

Rute Suntikan : Intramuskular

\section{Vaksin Hepatitis B}

Virus hepatitis B merupakan virus DNA yang termasuk dalam golongan Hepadnaviridae. Transmisi vertikal merupakan sumber infeksi utama di seluruh dunia, juga ditransmisikan melalui cairan tubuh, perkutan dan melalui membran mukosa, kontak dengan carrier hepatitis $\mathrm{B}$, hemodialisis, paparan terhadap peerja kesehatan yang terinfeksi, alat tato, alat tindik, hubungan seksual dan inseminasi buatan, juga dapat melalui transfusi darah dan donor organ. ${ }^{7}$

Imunisasi pasif Hepatitis B dapat dilakukan dengan pemberian imunoglobulin yang mengandung antiHBs. Sedangkan imunisasi aktif hepatitis $\mathrm{B}$ diperoleh melalui pemberian vaksin yang dihasilkan melalui berbagai cara, antara lain: hasil kultur HBsAg dari plasma pasien yang terinfeksi Hepatitis B kronik, memasukkan plasmid yang mengandung gen $\mathrm{S}$ virus.1

Vaksin diberikan dalm 3 dosis dengan jadwal 0 , 1, dan 6 bulan, bila setelah imunisasi terdapat respons yang baik maka tidak perlu dilakukan pemberian imunisasi penguat (booster).

Macam vaksin : antigen virus inaktif

Efektivitas : 75-90\%

Rute suntikan : intramuskular ${ }^{12}$

4. Vaksin Meningokokus

Vaksin meningokokus polisakarida tetravalen (A/C/Y/W-135) wajib diberikan pada calon haji dan dianjurkan untuk individu defisiensi, pasien asplenia anatomik dan fungsional dan pelancong ke negara yang terdapat epidemi penyakit meningokokus (misalnya "meningitis belt" di sub sahara Afrika). Vaksinasi ulang dipertimbangkan setelah 3 tahun.

Macam vaksin : polisakarida inaktif

Efektivitas : $90 \%$

Rute suntikan : subkutan $^{13}$

5. Vaksin Demam Tifoid

Dianjurkan penggunaannya pada pekerja jasa boga dan wisatawan yang berkunjung ke daerah endemis. Pemberian vaksin diulang setiap 3 tahun. ${ }^{1,6}$

Macam vaksin : antigen inaktif

Efektifitas : $: 50-80 \%$

Rute suntikan $\quad$ intramuskular ${ }^{14}$

\section{Vaksin Yellow Fever}

Vaksin ini diwajibkan oleh WHO bagi wisatawan yang berkunjung ke Afrika Selatan. Ulangan vaksinasi setiap 10 tahun. ${ }^{1,6}$

Macam vaksin : virus yang dilemahkan

Efektivitas : tinggi

Rute suntikan : subkutan

Vaksin ini mulai dikenal setelah perang amerika-spanyol dan menjadi endemik di Kuba, berkaitan dengan masalah sanitasi, dan meningkat angkanya setelah perang dunia ke II terutama di wilayah Afrika dan menjadi endemik. ${ }^{15}$ Vaksin yellow fever diperoleh dari strain 17D. Pada produksi awal vaksin di Amerika Serikat dan Brazil 1937-1941, dua derivat utama dari 17D (17D-204 dan 17DD) digunakan untuk produksi vaksin. Vaksin yellow fever ini memiliki angka serokonversi \pm 95\% pada anak-anak dan dewasa dan imunitas bertahan hingga 10 tahun. $^{16}$

\section{Vaksin Japanese Encephalitis}

Vaksin ini diberikan untuk wisatawan yang akan bepergian ke daerah 
endemis (Asia) dan tinggal lebih dari 30 hari atau akan tinggal lama disana. Terutama jika mereka melakukan aktivitas di pedesaan. ${ }^{1,6}$

Macam vaksin : virus inaktif

Efektivitas $\quad: 91 \%$

Rute suntikan : subkutan

Inactivated Japanese Encephalitis vaccine pertama kali dikembangkan tahun 1968, tetapi cakupan imunisasi masih rendah dan menunjukkan dampak pandemik yang signifikan pada tahun 1971-1972 terutama di China. ${ }^{17}$

Beberapa jenis vaksin Japanese encephalitis yang telah dikembangkan ada 4 yang tersedia dan terdaftar di internasional, dan mempunyai jadwal vaksinasi dan booster yang berbeda, yaitu: inactivated Vero cell culture vaccine $(J E-V C)$, inactivated mouse brain-derived vaccine (JE-MB), cellculture-derived live attenuated vaccine berdasarkan SA 14-14-2 dan live attenuated chimeric vaccine berdasarkan gen yellow fever $17 D$ backbone yang dikombinasi dengan Vero cell propagated SA 14-14-2 strain (IMOJEV). ${ }^{18}$

\section{Vaksin Rabies}

Vaksin ini bukan merupakan imunisasi rutin, dan dianjurkan pada individu yang beresiko tinggi tertular, wisatawan yang berkunjung ke daerah endemis yang beresiko kontak dengan hewan dan individu yang tergigit binatang tersangka rabies. ${ }^{1,6}$

Macam vaksin : virus yang dilemahkan, juga tersedia serum (rabies immnoglobulin)

Efektivitas : vaksin $100 \%$

Rute suntikan : intramuskular, subkutan

Sekarang ini, beberapa hal yang menjadi tantangan dalam perkembangan vaksin anti rabies pada manusia dan hewan adalah sedikitnya atau ketidaktersediaan teknologi modern untuk produksi nerve tissue vaccine (NTV) menjadi tissue culture (MTCV) atau vaksin sub-unit, karena NTV bukan hanya bersifat paralytogenic, tetapi kurang nyamam, kurang imunogenisitas, kurang toleransi dan kurang diterima oleh tubuh. ${ }^{19}$

\section{Vaksin Polio}

Beberapa negara bebas polio mungkin meminta bukti imunisasi polio pada saat mengurus visa kepada para pejalan dari negara-negara atau area yang masih ada virus polio liar (wild polio) yaitu Afganistan, India, Nigeria dan Pakistan. ${ }^{1,6}$

\section{EFEK SAMPING VAKSINASI}

1. Lokal

Reaksi lokal berupa bengkak dan nyeri pada tempat suntikan. Reaksi akan hilang dalam 48 jam dan biasanya sering terjadi pada suntikan intradermal. Pada umumnya pemberian vaksin akan dilanjutkan.

2. Sistemik

Reaksi sistemik dapat berupa demam, rasa lemah, nyeri otot dan nyeri kepala. Reaksi ini akan menghilang dalam 48 jam. Reaksi alergi (melalui Ig E) dapat terjadi namun jarang. Reaksi ini berupa urtikaria, angiooedema, anafilaksis setelah suntikan. Juga dapat terjadi reaksi imun kompleks meski jarang. Cara mengatasi reaksi sistemik sesuai dengan cara pengatasan reaksi alergi pada umumnya. ${ }^{6}$

\section{SIMPULAN}

Salah satu resiko kesehatan yang penting terkait perjalanan adalah resiko penularan penyakit dan penyebaran wabah yang dapat terjadi dengan sangat cepat ke seluruh dunia. Travel Vaccine atau vaksin wisatawan merupakan imunisasi khusus yang diberikan kepada para wisatawan 
sebelum mereka berpergian. Vaksinasi diyakini merupakan perlindungan primer utama dalam mencegah infeksi penyakit dan merupakan salah satu bentuk intervensi yang paling cost-effective untuk mencegah penularan penyakit infeksi selama perjalanan. Vaksin akan bekerja dua minggu setelah disuntik, jadi, waktu yang paling aman untuk melakukan suntik Travel Vaccine adalah satu bulan sebelum melakukan travel.

\section{DAFTAR PUSTAKA}

1. Sukamto Koesnoe, Samsurizal Djauzi. Dasar-Dasar Imunisasi Dalam Buku Ajar Ilmu Penyakit Dalam Edisi Keenam Jilid 1. Jakarta: InternaPublishing. 2014. 933-62

2. Peraturan Menteri Kesehatan Republik Indonesia No. 42 Tahun 2013 Tentang Penyelenggaraan Imunisasi

3. Erwanto Budi W. Imunisasi Dewasa Dalam Buku Ajar Ilmu Penyakit Dalam Edisi Keenam Jilid I. Jakarta: InternaPublishing. 2014. 951-57

4. Iris Rengganis, Robert Sinto. Aspek Imunologi Imunisasi Dalam Pedoman Imunisasi Pada Orang Dewasa. Jakarta: Balai Penerbit FKUI. 2012. 28-35

5. Guthrie SB et al. A Pathway to Leadership for Adult Immunization: Recommendations of the National Vaccine Advisory Committee Dalam Public Health Reports, 2012 Supplement 1, Volume 127

6. Samsuridjal Djauzi, Sukamto Koesnoe, Budi Amarta Putra. Konsensus Imunisasi Dewasa. Jakarta: Balai Penerbit FKUI. 2008

7. Samsuridjal Djauzi, Sukamto Koesnoe, Sari $\mathrm{C}$ et al. Pedoman Imunisasi Pada Orang Dewasa. Jakarta: Balai Penerbit FKUI. 2009
8. Immunization Action Coalition. Adult Only Vaccination: A Step by Step Guide, 2004

9. Primal Sudjana. Vaksinasi Pada Dewasa. Dalam Pedoman Penatalaksanaan Alergi dan Imunologi. Bandung: Perhimpunan Alergi Imunologi Indonesia (PERALMUNI). 111-17

10. CDC: Influenza Vaccination of Healthcare Personnel, MMWR, vol 55, February 9, 2006

11. Sagliocca L, Amoroso P, Straffolini T et al. Efficacy of Hepatitis A Vaccine in Prevention of Secondary Hepatitis A Infection: A randomized Trial. Lance 1999;353: 1136-39

12. Shen LP, Yang JY, Mo JZ et al. Variation of Hepatitis B Virus Infection Epidemic Pattern After Long Term HBV Vaccine Immunization. $J$ of Experimental and Clinical vir; 2017 : 253-55

13. Iris $\mathrm{R}$, Julitasari $\mathrm{S}$, Ardhi RA. Meningokokus DalamPedoman Imunisasi Dewasa. Jakarta; Balai Penerbit FKUI. 2012. 177-88

14. Marathe SA, Lahiri A, Chakravortty D. Typhoid fever \& vaccine development: a partially answered question Dalam Indian J Med Res volume 135(2). 2012. $161-9$

15. J. Gordon Frierson. The Yellow Fever Vaccine: A History dalam Yale Journal of Biology and Medicine 83. 2010. 7785.

16. Elizabeth D. Barnett. Yellow Fever: Epidemiology and Prevention. Dalam Clinical Infectious Diseases 2007; 44:850-6

17. Xiaoyan Gao, Xiaolong Li, Minghua Li et al. Vaccine Strategies for the Control and Prevention of Japanese Encephalitis 
in Mainland China, 1951-2011, PLOS Neglected Tropical Diseases Volume 8; Issue 8. 2014. e3015

18. Hui-Lan Chen, Jia-Kan Chang, Ren-Bin Tang et al. Current recommendations for the Japanese encephalitis vaccine dalam Journal of the Chinese Medical Association volume 78. 2015. 271-5

19. Ishaya Sini Tekki, Chika Nwosu, Philip Ademola Okewole. Challenges and Prospects of Anti-Rabies Vaccines Production in Nigeria dalam Journal Vaccines Vaccin volume 4. 2013. 8 